\title{
Organic geochemical and microscopical study of sedimentary organic matter, central West Greenland
}

\section{J. Perregaard and E. J. Schiener}

Sample material from shallow core hole drilling (187 core samples) and outcrops (more than 200 surface samples) were collected on Disko, Nûgssuaq and Svartenhuk Halvø during the summer of 1976 in a joint field programme between GGU and the Research Group for Organic Geochemistry of the Nuclear Research Establishment (KFA), Jülich, Federal Republic of Germany (Schiener \& Leythaeuser, 1978a). The samples have been studied in the laboratory both by organic geochemistry and by reflected light microscopy. The main objectives were the appraisal of the following parameters:

(1) Richness in organic matter.

(2) Maturation.

(3) Type of organic matter.

Special studies focused on the thermal influence of igneous intrusions on the organic matter in surrounding shales and the extent of weathering effects on organic matter in arctic areas.

Both the field programme and the establishment of an organic geochemical laboratory in GGU (Perregaard, 1978) were financially supported by the Danish Natural Science Research Council (SNF).

\section{Organic geochemistry}

The analytical techniques are outlined in Perregaard (1978). GLC analysis has been improved by installation of a glass capillary system in the HP 5840A gaschromatograph. High performance glass capillary columns offer the opportunity of making quantitative measurements of selected hydrocarbons by an internal standard calibration programme. Using this method concentrations of both selected saturated and aromatic hydrocarbons may be determined.

A brief appraisal of the petroleum potential of the Cretaceous-Tertiary sediments in the Nûgssuaq Embayment is reported in Schiener \& Leythaeuser (1978b). Detailed organic geochemical studies of a series of sediment sequences have confirmed the main conclusions in this report. Sediment samples have generally proved to be extremely rich in organic matter ( $\mathrm{C}_{\text {org }} \gg 3$ per cent). Regionally the organic matter is immature and is predominantly derived from higher plants. $\mathrm{C}_{15}+$ extracts are generally rich in polar NSO compounds and saturated hydrocarbon fractions are dominated by heavy end $n$-alkanes exhibiting high carbon preference indices (CPI $>1.4)$. The high proportion of ligneous/humic constituents render these sediments unfavourable for generation of commercial quantities of liquid hydrocarbons but they can be considered as a rich source for gaseous hydrocarbons by burial to adequate depths.

In the south-eastern part of Nûgssuaq dark shales of Paleocene age (Naujât Member) are present. These shales have an organic carbon content in the range of $8-15$ per cent. The 
Saturated

Hydrocarbons

177685
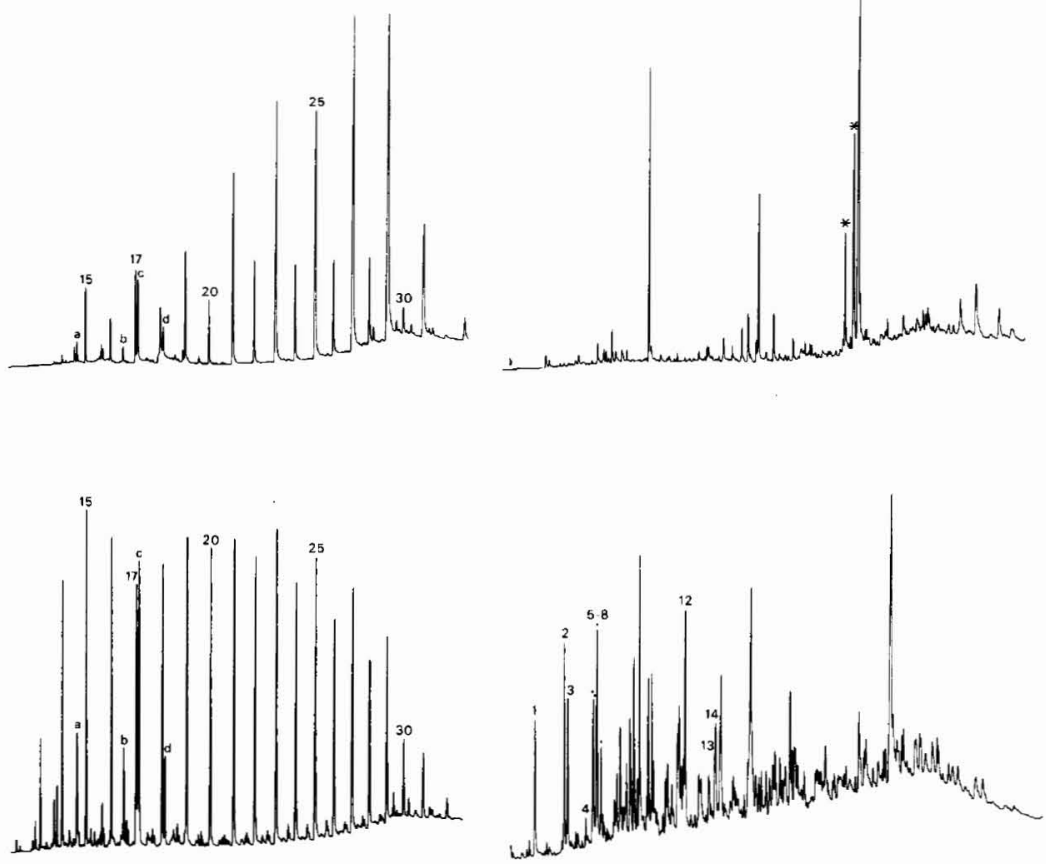

177681
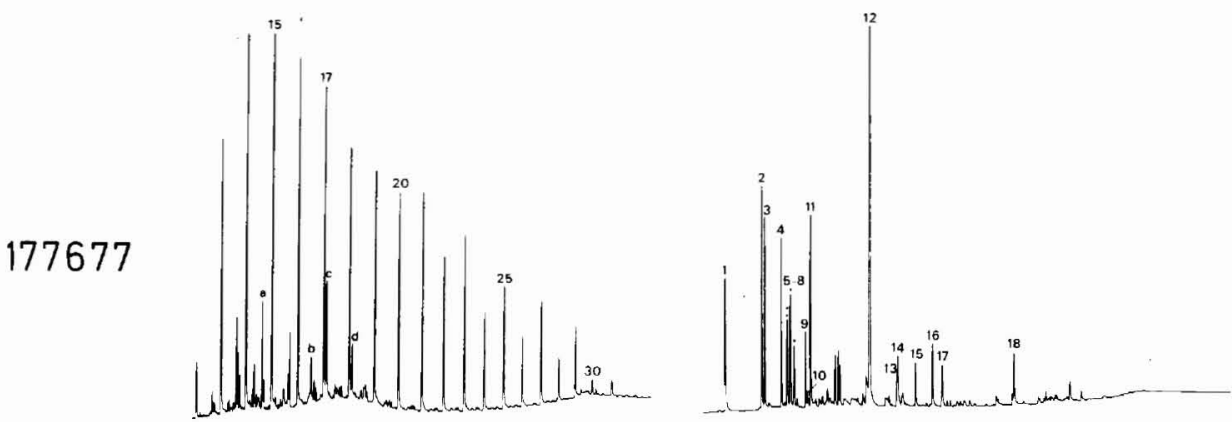

Fig. 21. GLC chromatograms of saturated and aromatic hydrocarbon fractions.

Saturated hydrocarbons. Peak identification no. corresponds to chainlength of $n$-alkane. a: $\mathrm{C}_{16}$-isoprenoid; b: norpristane; c: pristane; d: phytane.

Aromatic hydrocarbons: Peaks marked with an asterisk correspond to tetracyclic triaromatics. 1 : naphthalene; 2: 2-methylnaphthalene; 3: 1-methylnapthalene; 4: biphenyl; 5-8: dimethylnaphthalenes; 9-10: methylbiphenyls; 11: dibenzofuran; 12: phenanthrene; 13-14: methylphenanthrenes; 15: m/e $204\left(\mathrm{M}^{+}\right) ; 16: \mathrm{m} / \mathrm{e} 202\left(\mathrm{M}^{+}\right) ; 17:$ pyrene; 18: chrysene. 
Table 4. Organic geochemical data and vitrinite reflectance measurements

\begin{tabular}{|c|c|c|c|c|c|c|c|c|}
\hline $\begin{array}{l}\text { GGU } \\
\text { sample no }\end{array}$ & $\begin{array}{l}\text { Distance from } \\
\text { basaltic dyke } \\
\text { margin }\end{array}$ & $c_{\text {org }}$ & $\begin{array}{l}\text { EOM extract. } \\
\mathrm{mg} \text { EOM/g Corg }\end{array}$ & $\begin{array}{l}\text { HC extract. } \\
\mathrm{mg} \text { EHC/g } C_{\text {org }}\end{array}$ & $\begin{array}{l}\text { Sat.HC } \\
\text { ppm }\end{array}$ & $\begin{array}{l}\text { Aromatic HC } \\
\text { pprn }\end{array}$ & $\begin{array}{l}\text { NSO } \\
\mathrm{ppm}\end{array}$ & $F_{\mathrm{m}} \%$ \\
\hline 177685 & $7.0 \mathrm{~m}$ & $7.04 \%$ & 6.4 & 2.9 & 59 & 61 & 234 & 0.32 \\
\hline 177681 & $3.0 \mathrm{~m}$ & $10.18 \%$ & 28.7 & 20.1 & 1509 & 536 & 803 & 1.43 \\
\hline 177677 & $0.5 \mathrm{~m}$ & $9.59 \%$ & 3.6 & 1.0 & 12 & 91 & 121 & 2.25 \\
\hline
\end{tabular}

thermally immature organic matter is locally influenced by the heat effects of igneous intrusions resulting in localized maturation with associated generation of hydrocarbons. To demonstrate the effect of this localized heating the results of organic geochemical analyses of three samples are presented. The samples were collected from a single bed in three different temperature zones with respect to a dyke (Table 4).

Sample GGU 177685 ( $7.0 \mathrm{~m}$ from dyke contact) is immature for the generation of hydrocarbons. This is clearly indicated by the GLC chromatograms of the saturated and aromatic hydrocarbons (fig. 21). A predominance of heavy end $n$-alkanes with odd numbers of carbon atoms is found. These alkanes are thought to originate from higher plant waxes and long chain fatty acids. Few prominent peaks are present in the aromatic chromatogram corresponding to partially aromatized polycyclic structures. Peaks marked with an asterisk correspond to triaromatic tetracyclic compounds which also have been documented from the Messel oil shale (Spyckerelle et al., 1977).

The organic matter in sample GGU 177681 (3.0 $\mathrm{m}$ from dyke contact) is mature. One of the characteristics of this maturation is the generation of appreciable amounts of hydrocarbons in the $\mathrm{C}_{15}+$ range (EHC, Table 4). An almost even distribution of $n$-alkanes in the range $n-\mathrm{C}_{15}$ to $n-\mathrm{C}_{29}$ with a slight predominance of odd numbered $n$-alkanes in the heavy end (fig. 21) is present. The aromatic fraction is of very complex composition similar to that of most crude oils.

Sample GGU 177677 ( $0.5 \mathrm{~m}$ from dyke contact) is taken close to the dyke in the eometamorphic zone. A light end predominance of both saturated and aromatic hydrocarbons indicates severe thermal alteration of this sample (fig. 21). The dominating presence of small, condensed, unsubstituted or methyl substituted aromatics is especially indicative of eometamorphism. As these aromatics are thermally more stable than the $\mathrm{C}_{15}+$ saturated hydrocarbons, the aromatic fraction constitutes the main part of the $\mathrm{C}_{15}+$ hydrocarbons (Table 4). Changes in composition of aromatic fractions have been studied as a function of burial (Tissot et al., 1971). At shallow depths high molecular weight naphtheno-aromatic compounds generally containing a high number of naphthenic rings are present. In deep samples smaller, purely aromatic molecules of naphthalene and phenanthrene types become increasingly important. Total predominance of phenanthrene and increasing relative abundance of biphenyl are found well into the eometamorphic temperature zone (Perregaard \& Schiener, in press). In immature samples biphenyl has not been detected and only in the oil generating zone does it gradually begin to appear in the chromatograms. 

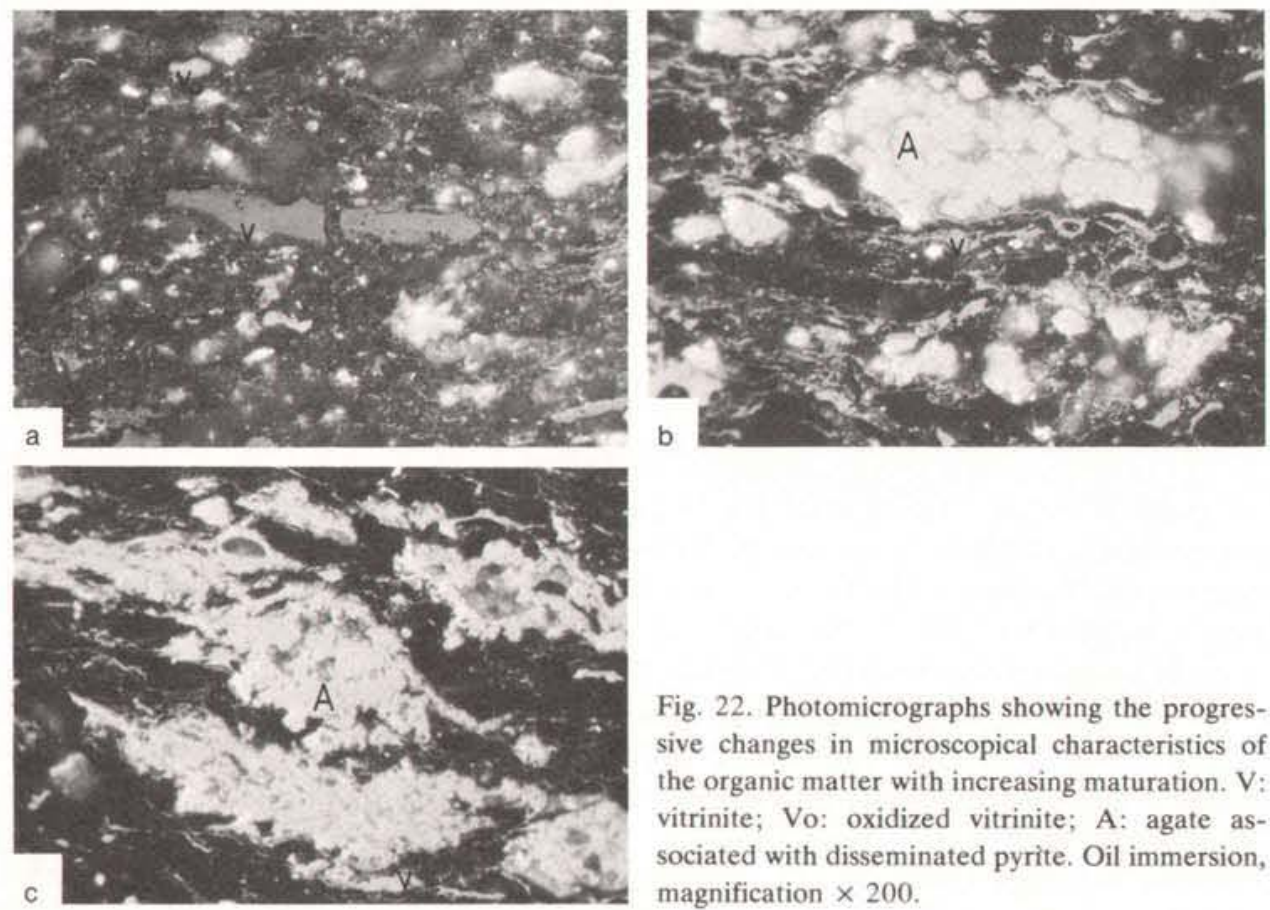

Fig. 22. Photomicrographs showing the progressive changes in microscopical characteristics of the organic matter with increasing maturation. V: vitrinite; Vo: oxidized vitrinite; A: agate associated with disseminated pyrite. Oil immersion, magnification $\times 200$.

\section{Microscopy}

Organic matter in the Naujât shales has been studied with reflected white light microscopy as well as with UV-induced fluorescence microscopy in whole rock preparations. The latter approach provides the only reliable geochemical appraisal of the amount and type of exinitic components in the organic matter, considered to be the main contributors to the extractable organic matter. Lithologically the Naujât shales are fairly uniform. Clay minerals have not yet been studied, but would provide valuable data for a regional approach.

Microscopically observable organic matter in immature samples consists of approximately 50 per cent exinitic, predominantly non-figured material, of approximately 35 per cent vitrinictic components (both slightly oxidized and nonoxidized) and 15 per cent inertinitic fragments (fig. 22a). The origin of the exinitic fraction cannot be determined from microscopic evidence. Chemical evidence, however, suggests that wax-rich exines were the precursors of the fluorescent material which now appears amorphous. The thin and discontinuous vitrinite bands represent remains of gelified ligneous/humic parts of higher vascular plants. Thermal effects on the organic matter are microscopically detectable. The most extensively studied changes refer to a gradual increase in reflectance of the vitrinite component concurrent with exposure to increasing temperatures (Teichmüller, 1970; Bostick, 1971; Suggate, 1974). This process is considered to be irreversible with decreasing temperature regime and thus provides a 'maximum thermometer' reading. However, the correlation of reflectance to absolute temperatures is somewhat conjectural, despite the intensive 
study of both natural and laboratory conditions. The maturation stage, as indicated by vitrinite reflectance values, is influenced both by the maximum palaeotemperatures and the time the organic matter has been exposed to these temperatures. Laboratory experiments cannot account for the influence of geological time on the physico-chemical reactions, the only way to compensate for the time factor being with higher reaction temperatures.

Conditions intermediate between the slow, geological maturation-by-burial process and the fast, high temperature laboratory process may be provided by the thermal effects of igneous intrusives (Sauvan, et al., 1975).

The organic geochemical characteristics of the three samples representing the three main maturation phases have been described above. The corresponding microscopical aspects are described below.

In sample GGU 177685 (fig. 22 a) vitrinite/huminite (V) occurs in low reflecting $\left(R_{\mathrm{m}}=\right.$ 0.34 per cent) microscopic seamlets and as discontinuous wisps of equally low reflectance. Oxidized vitrinite (Vo) is readily distinguished. Exinitic material is only recognizable with certainty under blue UV-radiation. Under white light its granular appearance with brownish interior reflexes occasionally assists in identification. The nonfigured exinitic material has yellow-green fluorescence colours displaying positive alteration (Teichmüller, 1974). Morphologically it appears as agglomerations of flattened globules. The few figured components (microspores and fragments of cuticles) fluoresce with reddish colours whereas the occasional resin globules display a dull brownish fluorescence.

In sample GGU 177681 (fig 22b) vitrinite has not significantly changed in morphology but its reflectance is increased to $R_{\mathrm{m}}=1.43$ per cent. Oxidized vitrinite and inertinitic fragments are no longer distinguishable by their different reflectance, only morphological characteristics permit their differentiation from vitrinite.

Observation under UV-radiation reveals continuing fluorescence of exinitic macerals. The fluorescence intensity is only slightly reduced and a colour shift towards red and brown is noticeable. There has apparently been mobilization of some fluorescing substances. Silica is seen to be redistributed by an aqueous phase, and was deposited as agate filling fissures and pores on a microscopic scale. Yellow fluorescing material is commonly associated with these agate filled veins.

Sample GGU 177677 shows distinct changes of the organic matter in line with the high reflectance of $R_{\mathrm{m}}=2.25$ (fig. $22 \mathrm{c}$ ). Vitrinite bands are reduced to thicknesses below $3 \mu \mathrm{m}$ and appear as strongly disrupted wisps. Some incipient vesiculation of vitrinite is recognizable, whereas structural features of fusinite remain unchanged. Agate (A) occurs in large irregular patches associated with pyrite, as well as in veins and fissures.

Under UV-light fluorescence of exinites has disappeared, but fluorescence associated with agate is preserved despite the degree of thermal alteration.

\section{Conclusion}

The results of investigations to date have revealed some unique aspects of the Naujât shales with respect to governing environmental factors during their deposition. These rather specific characteristics would merit more regional mapping and sampling of this lithological unit in order to arrive at a more definite and better documented depositional model. 


\section{References}

Bostick, N. H. 1971: Thermal alteration of clastic organic particles as an indicator of contact and burial metamorphism in sedimentary rocks. Geosci. Man. 3, 83-92.

Perregaard, J. 1978: Establishment of an organic geochemical laboratory in GGU. Rapp. Grønlands geol. Unders. 90, 150-154.

Perregaard, J. \& Schiener, E. J. in press: Thermal alteration of sedimentary organic matter by a basalt intrusive (Kimmeridgian Shales, Milne Land, East Greenland). (Submitted to Chemical Geology, in 1978).

Sauvan, P., Esquevin, J. \& Chennaux, G. 1975: Transformation induites par des intrusions doléritiques dans une série argileuse: l'Ecca de Bergville (Afrique du Sud). Bull. Centre Rech. Pau-SNPA 9, 2, 261-351.

Schiener, E. J. \& Leythaeuser, D. 1978a: Shallow core hole drilling and sampling for the investigation of organic matter rich shales in 1976, Nûgssuaq, central West Greenland. Rapp. Grønlands geol. Unders. 90, 29-32.

Schiener, E. J. \& Leythaeuser, D. 1978b: Petroleum potential off W. Greenland. Oil Gas J. 76(40), 223-234.

Spyckerelle, C., Greiner, A.Ch., Albrecht, P. \& Ourisson, G. 1977: Aromatic hydrocarbons from geological sources part III. A tetrahydrochrysene derived from triterpenes in recent and old sediments: 3,3,7-trimethyl-1,2,3,4-tetrahydrochrysene. J. Chem. Res. (M) 1977, 3746-3777.

Suggate, R. P. 1974: Coal ranks in relation to depth and temperature in Australian and New Zealand oil and gas wells. N. Z. J. Geol. Geophys. 17, 149-167.

Teichmüller, M. 1970: Bestimmung des Inkohlungsgrades von kohligen Einschlüssen in Sedimenten des Oberrheingrabens - Ein Hilfsmittel bei der Klärung geothermischer Fragen. In Illies. J. H. \& Müller, S. (edit.) Graben Problems, 124-142. Stuttgart: Schweizerbarth'sche Verlagsbuchhandlung.

Teichmüller, M. 1974: Über Macerale der Liptinit-Gruppe und die Entstehung von Micrinit. Fortschr. Geol. Rheinld. $u$. Westf. 24, 37-64.

Tissot, B., Califet-Debyser, Y., Deroo, G. \& Oudin, J. L. 1971: Origin and evolution of hydrocarbons in Early Toarcian Shales, Paris Basin, France. Bull. Amer. Ass. Petrol. Geol. 55, 2177-2193. 